\title{
Eurasian Cooperation in the Relationship Between Economic Security and Inter-Ethnic Relations
}

\author{
Natalia L. Kurepina \\ Department of economic security, accounting and finances \\ FSBEI HE Kalmyk State University named after B.B. \\ Gorodovikov \\ Elista, Russia \\ kurepinanl@mail.ru
}

\author{
Maria V. Shovaeva \\ Department of civil law \\ FSBEI HE Kalmyk State University named after B.B. \\ Gorodovikov \\ Elista, Russia
}

\begin{abstract}
In Russia, China's initiatives for the implementation of the "One Belt, One Road" (一带一路) project are met with great interest, the resumption of discussions was facilitated by a joint statement on cooperation on the construction of the Eurasian Economic Union and The Silk Road Economic Belt (丝绸之路经济带), signed following the RussianChinese summit in 2015.

The author of the article believes that when considering the problems and prospects for the development of Eurasian cooperation in education and science, it is better to use the term "Eurasian integration." The author considers the issues of Eurasian integration in the fields of scientific and educational activities on the example of Kalmyk State University, in which, as a result of joint activities with Chinese partners, a program of academic exchanges has been developed, and the Confucius Institute has been operating since 2007.

The author examines the issues of academic mobility taking into account both economic security and interethnic relations, their mutual influence on each other. The data of sociological surveys on the relationships between different ethnic groups among students are presented, and a conclusion on the need to monitor interethnic relations in the region is drawn.

Considering individual threats that may negatively affect the security of integration processes, the author still concludes that there is a need to deepen cooperation in science and education, which will allow to set the pace of the process of the unified Eurasian integration.
\end{abstract}

Keywords: China, Russia, Kalmykia Republic, economic security

\section{INTRODUCTION}

At the Forum of Heads of State and Government "One Belt, One Road" (The New Silk Road Project), held in Beijing on May 14-15, 2017, Vladimir Putin announced fundamentally new provisions defining trends of international and national economic security.
As an alternative to overcoming stagnation in global economic development he proposed a mega project of Greater Eurasia as a great Eurasian partnership based on justice, equality, respect for national sovereignty, on international law and the unshakable principles of the United Nations.

One of the areas of development is Eurasian integration in education and science, which is undoubtedly necessary and in the long term will allow greater use of the potential of interpersonal contacts for cooperation in regional development, and will also improve the quality of higher education in Russia and in the region as a whole.

Educational institutions play an important role in the development of integration processes, in the region under study Kalmytsky State University is doing a lot for the implementation of this project, which is ultimately aimed at safe, comfortable human development in the polyethnic region of Republic of Kalmykia.

\section{LITERATURE REVIEW}

The Silk Road Economic Belt (SREB) and the Eurasian Economic Union (EAEU) projects are united by close, noncontradictory cultural norms; both projects are aimed at the development of Eurasian cooperation [1].

However, there is no consensus among Russian experts and scientists on the implementation of projects. Some believe that despite the so-called strategic partnership, Moscow and Beijing are competitors in Eurasia; that China sees the creation of the EAEU as a threat to its economic and geopolitical interests, and the SREB project, as opposed to the EAEU, will strengthen China's position in Central Asia and shut down the flow of goods from the Southeast Asia to Europe.

Others believe that Russia and China are quite capable of dialogue within this project, which will allow to act upon a unique chance to create a single space of cooperation from the Atlantic to the Pacific, to reduce the colossal gap in the 
The situation of accepting migrants of a different development level of countries and regions, neutralize the breeding ground for international terrorism, extremism, and illegal migration [2].

At the same time, there are concerns that the project will bring about security issues.

Thus, E.A. Safonova in [3] believes that the project "One Belt, One Road" and the implementation of its sub-project SREB involves a number of risks not only for partner states, but also for China itself.

An important problem that China will inevitably face in the practical implementation of the SREB project in Central Asia, says K.L. Syroyezhkin [4], is the need for its increased participation in regional security.

Thus, because of Washington's policy in Afghanistan, there is a real threat that terrorists and separatists will infiltrate from the Islamic Republic of Afghanistan to the People's Republic of China, which will negatively affect security in the Xinjiang Uygur Autonomous Region, where some SREB routes are planned [5].

A number of authors, during the study of the development of the Eurasian space, consider questions of deepening cooperation in the field of science and education [6].

R.A. Udaev [7] considers ethnocultural aspects of national security, he believes that "uncontrolled ethnic migration of the population leading to the emergence of new ethnocultural conflicts" and other manifestations of ethnoseparatism are a serious threat to national security.

Ms. Andreea Brînză, Vice-President of the Romanian Institute for the Study of the Asia Pacific, believes that during recent years the attitude towards the One Belt One Road project has not changed for the better. The European Union was among the first to state their concern with Chinese presence at their territory and correspondingly started to introduce measures aimed at limiting and opposing Chinese expansion [8].

The experience of international student exchange shows that assembling students from different countries at universities not only significantly expands and increases the cultural and educational level of students in higher education institutions, but also influences the development of the country and generally contributes to overall political and economic stability [9].

A review of publications by foreign and Russian scientists has shown that opinions about the One Belt One Road [10] project are mixed, especially in recent years, as there has been concern about China's expansion in the European Union. The problems of Eurasian cooperation require additional research and forecasting of economic consequences.

The object of research-the Republic of Kalmykia-has historical roots of connection with China and other countries of the East, which go back for centuries, for example, the Great Silk Road passed through the territory of the republic in the 8 th century. [11]. nationality as citizens of the republic is quite relevant since it affects the interests of people living in the republic, first of all it reduces the ratio of the titular nation. In general, according to survey, over $80 \%$, irrespective of their ethnic and territorial identity, are ready "to accept a person of a different nationality as a citizen of the republic"[12].

The region stands out in its ethnocultural and ethnoconfessional characteristics, which should be reflected in scientific analysis, in the assessment of economic security as a result of integration processes.

\section{METHODS}

The proposed study covers from a systemic perspective the main significant aspects of the problem being analyzed: the issues of Eurasian integration, and the specifics of the development of these processes in the polyethnic region.

The study applies the principles of objectivity, accounting for the change and development of the research phenomenon, systemicity and holistic approach to the research subject, the methods of mass surveys, expert surveys, content analysis, structural-functional, economic and logical analysis.

\section{RESUlTS}

Eurasian integration in the field of education and science is undoubtedly characterized by positive features, allowing Russian universities to enter the international educational space. However, attracting international students to study in Russia and increasing their number in Russian universities can create certain problems in the field of economic security.

International integration processes in education and science have recently become large-scale.

The number of international students has almost tripled, and the number of students from CIS countries has increased more than four times (Table I).

\section{TABLE I. NUMBER OF INTERNATIONAL STUDENTS}

\begin{tabular}{|l|l|l|l|l|l|}
\hline & $\mathbf{2 0 0 0}$ & $\mathbf{2 0 0 5}$ & $\mathbf{2 0 1 6}$ & $\mathbf{2 0 1 7}$ & $\begin{array}{c}\text { 2017 as a } \\
\text { percentage } \\
\text { of 2000 }\end{array}$ \\
\hline $\begin{array}{l}\text { International } \\
\text { students, } \\
\text { units }\end{array}$ & 58992 & 78139 & 175412 & 153586 & 260.4 \\
\hline $\begin{array}{l}\text { Among them } \\
\text { citizens of } \\
\text { CIS } \\
\text { countries, the } \\
\text { Baltic States, } \\
\text { Abkhazia } \\
\text { and South } \\
\text { Ossetia, units }\end{array}$ & 34510 & 40636 & 134500 & 147080 & 426.2 \\
\hline $\begin{array}{l}\text { Percentage } \\
\text { of the total } \\
\text { number of } \\
\text { students, \% }\end{array}$ & 1.4 & 1.3 & 4.5 & 5.2 & - \\
\hline
\end{tabular}

The same trend is typical for the countries of the Eurasian Economic Union, according to the statistics of the Ministry of 
affects a stable, balanced position in society, required for its development (see Table II). of studying in 2018, which is twice as many as in 2007. According to the Ministry of Education and Science of the Russian Federation, more than 30.0 thousand citizens of The People's Republic of China are getting higher education in 85 Russian cities [13].

Our research has been carried out in a multi-ethnic region characterized by threats to economic security in various areas, but it is especially important for a region with a complex ethnic and religious composition to diagnose them in the youth environment in a timely manner and to prevent them quickly.

The Republic of Kalmykia is home to about 100 nationalities, three relatively large ethnic and religious communities (Buddhists, Orthodox Christian, Muslims), which determines the specifics of the region [14].

The survey of Kalmyk youth showed that almost $30 \%$ of respondents are determined to leave the region. But foreign migrants are arriving. The vast majority are citizens of Uzbekistan ( $80 \%$ of the total), the others are mostly citizens of China. The first are usually engaged in construction, trade, the second - in vegetable production. There is an expert forecast that in the foreseeable future a number of migrants from Caucasian mountains to Kalmykia will increase as they are moving from Russian republics with increased population growth. The growing number of migrants from Central Asia has begun to alarm the Kalmyk public.

There has also been a marked increase in international students from 74 in 2011 to 700 today. The majority of them are from the Eastern countries: China, Syria, Mali, South Korea, Sri Lanka, Vietnam, etc [15].

Assessing the relationship between economic security and inter-ethnic relations for polyethnic depressive regions is especially important. On the one hand, economic vulnerability and economic disadvantage in the region can negatively affect the socio-economic situation, the well-being of certain ethnic groups and their relations. On the other hand, anxiety, tension, and even more so, conflicts in the field of inter-ethnic communications, have a negative impact on the state of economic security.

To this end, sociological surveys were conducted and websites were analyzed. Most of the respondents were students of different ethnic groups: Kalmyks- $55.6 \%$ of the sample population; Russians-23.0\%; representatives of other ethnic groups-21.4\%.

The sample population used in our study is dominated by young people, mostly students, as they, being a strong resource, adapt to market conditions faster and are focused on business success. Young people, having the necessary modern knowledges (information technologies, foreign language), professions in demand in the labor market, financially prosperous, have inflated requirements for comfort and leisure activities.

Surveys on the socio-psychological state showed that a positive socio-psychological state $(53 \%)$ dominates, which
TABLE II. STUdENT RESPONSES TO THE SURVEY OF THEIR SOCIAL AND

\begin{tabular}{|l|l|l|l|l|}
\hline № & \multicolumn{1}{|c|}{ Options } & Kalmyks & Russians & \multicolumn{1}{|c|}{$\begin{array}{c}\text { Other } \\
\text { ethnic } \\
\text { groups }\end{array}$} \\
\hline 1 & Emotional uplift & 7.3 & 4.8 & 11.1 \\
\hline 2 & Calm, poise & 47.3 & 3.2 & 44.4 \\
\hline 3 & Optimism, pep & 12.0 & 22.6 & 25.0 \\
\hline 4 & $\begin{array}{l}\text { Indifference, } \\
\text { apathy, depression }\end{array}$ & 22.7 & 19.3 & 2.7 \\
\hline 5 & Anxiety, fear & 4.7 & 11.3 & 2.7 \\
\hline 6 & $\begin{array}{l}\text { Irritation, anger, } \\
\text { aggression }\end{array}$ & 5.3 & 1.6 & 2.7 \\
\hline
\end{tabular}

Only a quarter of respondents $(25 \%)$ characterized their socio-psychological state as negative, including indifference, apathy, depression (16\%), anxiety, fear (5.5\%), irritation, anger, aggression $(3.8 \%)$. About a half of the respondents possess calmness and poise. Almost one in six respondents is in a state of optimism and cheerfulness. We can summarize that the economic crisis did not contribute to the strengthening of catastrophic perception of reality by the inhabitants of the republic.

Of course, the socio-psychological state has an impact on the confidence/uncertainty of an individual. A confident state allows us to make plans in accordance with our vital interests, ensuring the development, safety and economic security of an individual. Sadly, a fifth pf the respondents are not confident in the future $(22.5 \%)$. Those are the ones in a negative sociopsychological state (see Table III).

TABLE III. DISTRIBUTION OF ANSWERS TO THE QUESTION "DO YOU FEEL CONFIDENT IN THE FUTURE?" (PERCENTAGE BY GROUP)

\begin{tabular}{|l|l|l|l|}
\hline \multicolumn{1}{|c|}{ Options } & \multicolumn{1}{|c|}{ Kalmyks } & Russians & $\begin{array}{c}\text { Other ethnic } \\
\text { groups }\end{array}$ \\
\hline Yes & 56.0 & 45.2 & 55.0 \\
\hline No & 20.0 & 35.5 & 20.0 \\
\hline It's hard to answer & 24.0 & 19.3 & 25.0 \\
\hline
\end{tabular}

Understanding the nature and causes of the sociopsychological state of the population requires an analysis of how satisfied they are with the various aspects of their daily lives. Analysis of the survey data suggests that the level of overall satisfaction of residents by different aspects of their own lives is quite stable. There is a high degree of good assessment and satisfaction, while the number of "bad" grades is at the minimum or even absent.

We should note that the favorable psychological and interethnic climate of the republic, despite the insufficiently prosperous economic condition, contributes to the development of integration processes in the field of education and science. The result of the joint activities of Chinese partners and Kalmytsky State University is not only the growth of academic mobility, the expansion of intercultural activities, and academic exchanges. Additionally, Confucius Institute has been operating on the basis of the KalmSU since PSYCHOLOGICAL STATUS (\%) 


\section{REFERENCES}

2007, and it hosts a large number of events and projects that contribute to the growth of understanding of Chinese history, culture and traditions in Russia. Thanks to financial support from the Confucius Institute's headquarters, the Centre for the Understanding of Chinese Language and Culture was opened on the basis of the Scientific Library of Kalmytsky University, and scientific teams are being created.

\section{CONCLUSIONS}

Integration processes in the field of education and science, which are very characteristic of the Republic of Kalmykia, are undoubtedly important and necessary. Kalmytsky State University is doing a lot of work in this direction. The Republic of Kalmykia, as a multi-ethnic and multi-religious region, is characterized by a favorable inter-ethnic regional climate.

However, the results of ethnomonitoring show the concern of the Kalmyk community with the increasing migration outflow of the republic's inhabitants, including the titular population, and the increase in the influx of citizens from the other countries, particularly those from Central Asia. This fact forces regional and local authorities to take measures aimed at socializing migrant workers from abroad, building relations between arriving people and the old-timer population, and preventing possible conflicts on the domestic and inter-ethnic basis. National cultural organizations should pay the necessary attention to adapting their compatriots, arriving to live, work, or study in Kalmykia.

Therefore, the need to monitor and pay more attention to issues of inter-ethnic relations, understanding their role in ensuring the economic security of the region, should become an important task for the state authorities.

\section{ACKNOWLEDGMENT}

The article was prepared with the support of the Russian Federal Property Fund in the framework of the project No. 19010-00796 "Improving the methodology for assessing the economic security of a poly-ethnic region: an interdisciplinary approach".
[1] A. V. Ostrovsky, "Chinese project "Silk Road Economic Belt" as a path to international economic cooperation", Asia and Africa Today, vol. 2 (703), 2016, pp. 8-12.

[2] A. E. Gorodetsky, "Russia's Economic Security: A New Strategy in a New Reality", 2017 [Electronic resource]. Available at: elibrary_31228401_54672830.pdf.

[3] E. I. Safonova, "Silk Road Economic Belt Project and Security in Central Asia", Problems of the Far East, vol. 4, 2018, pp. 23-30 [Electronic resource]. Available at: https://ras.jes.su/pdv/s013128120000151-7-1.

[4] K. L. Syrojezhkin, "Silk Road Economic Belt Project in the complex space of Central Asia", Contours of global transformations, vol. 9 (6), 2016, pp.104-121.

[5] D. V. Gordienko, "Prospects for changes in the economic security of SCO member states in the implementation of the Silk Road Economic Belt Strategy; the Strategy of the Silk Road Economic Belt and the role of the SCO in its implementation", in Materials of the round table IDV RAS, Moscow, IDV RAS, March 2016.

[6] L. N. Smirnova, "On the concept of the "Eurasian space of higher education". The Strategy of the Silk Road Economic Belt and the role of the SCO in its implementation", in Materials of the round table IDV RAS, Moscow, IDV RAS, March 2016.

[7] R. A. Udaev, "Security and identity: ethnocultural aspects", Kalmytsky University Herald, vol. 4, 2018, pp. 156-166.

[8] Tszeya Lyu, "The development of international scientific and educational cooperation between China and Russia within the framework of the "One Belt One Road" project", Young scientist, vol. 47, 2017, pp. 65-69 [Electronic resource]. Available at: https://moluch.ru/archive/181/46755/ (Accessed: 23 December 2019).

[9] Andreea Brînză, "From growth opportunity to threat: how the world has changed its mind on China's belt and road", South China Morning Post, Hong Kong [Electronic resource]. Available at: https://www.scmp.com/comment/insight-opinion/hongkong/article/2176536/growth-opportunity-threat-how-world-haschanged.

[10] "The Strategy of the Silk Road Economic Belt and the role of the SCO in its implementation", in Materials of the round table IDV RAS, Moscow, IDV RAS, March 2016

[11] K. N. Maximov, "History of Kalmykia from Ancient Times to the Present Day: in three volumes", Elista: Gerel House, 2009, vol. 1, pp. 848-877.

[12] N. L. Kurepina, M. V. Shovaeva, N. B. Berikova, and L. V. Namrueva, "Economic security of a polyethnic region: experience and new challenges", European Proceedings of Social and Behavioral Sciences, 2019, pp. 742-750.

[13] Website https://www.5top100.ru/news/104492/.

[14] Website of the Russian State Statistics Committee www.gks.ru.

[15] Website of the Kalmyk State University www.Kalm.su 